\title{
Professional Teacher Guidance in Indonesia
}

\author{
Mochamad Cholik \\ Mechanical Engineering Department \\ Universitas Negeri Surabaya \\ Surabaya, Indonesia \\ mochamadcholik@unesa.ac.id
}

\author{
Triyanto Pristiwaluyo \\ Faculty of Science Education \\ Universitas Negeri Makasar \\ Makasar, Indonesia
}

\begin{abstract}
The population in this research is all teachers who receive professional allowance in 2016 in all provinces of Indonesia. Samples of province were 13 provinces and those of teachers were 195. Data collection used was self-assessors. The data were analyzed descriptively, both quantitative and qualitative. The purpose of this study was to obtain information on a) Descriptive Declaration Performance and Professional Allowance, b) The Influence of Professional Teacher Allowance on Teacher Performance as Educator, c) The Influence of Professional Teacher Allowance on Teacher Professionalism. The results of this research were as follows: There is a positive relationship between professional teacher allowances with the performance of teachers as educators and there is no relationship between professional teacher allowances with teacher professionalism.
\end{abstract}

Keyword-allowances teacher, performance

\section{INTRODUCTION}

The existence of qualified teachers is a necessary condition for successful educational systems and practices [1]. The study about teacher professionalism and the state in the twenty-first century was beginning by sociological literature [2], almost all nations of the world are now developing policies that encourage to be qualified teachers [3]. One of the policies developed by governments in many countries is the policy of direct intervention towards quality improvement and providing adequate teacher guarantees and welfare [4]. Another policies example that used in China is remuneration that can improve the quality of education by making teachers more diligent and creative that can remove the inequality between teachers in different school [5]

The task of the education personnel is to plan and implement the learning process, to assess the learning outcomes, to conduct guidance and training, and to conduct research and community service [6], especially for educators in universities. The planning and implementation of the learning and assessment of the outcome is a series, for learning, training and mentoring activities [7]. In addition, teachers also as professionals are obliged to develop the educational profession [8]. The intention was to improve the quality of education by making teachers more diligent and creative and removing the inequality in pay between teachers in different schools. Thus, the task of the teacher can be simplified into teaching, training, guiding and developing the educational profession [9]. Professionalism, Professionality, and control is a key of rising standard and increase societal growth [10]. The above description leads to the question of: how is the performance of teachers as educators and as professionals in relation to teacher allowances already received?

The research aims to find out: a) Effect of teachers' professional allowance on teacher performance as an educator; b) Effect of professional teacher allowance on teacher professionalism.

\section{METHOD}

The population of this study was all teachers who receive teacher professional allowance, which is spread over all provinces in Indonesia until 2016. Samples of the province were 13 provinces and those of respondents were 195 teachers. Samples were taken at random Data collection using closed questionnaire with Self Appraisal model. Assessment includes the ability to master the subject matter taught, the understanding of students who are taught, the ability to design and implement learning, and professional skills and career development. Data analysis techniques used were descriptive analysis, both quantitative and qualitative.

\section{Result AND Discussion}

\section{A. Descriptive Declaration Performance and Professional Allowance}

Base on data analysis, the following was obtained: As much as $10.35 \%$ of the respondents gave a negative response to Declaration Performance and Professional Allowance Disbursement in the determination the criteria of beneficiaries. This means that the Declaration Performance and Professional Allowance Disbursement in determining the beneficiaries is not fully in accordance with the criteria of beneficiaries who have been determined.

There are teacher professional allowance recipients who do not meet the minimum criteria of teaching hours of the provisions, i.e. 24 hours per week on the same subject, yet they have NUPTK.

There are $11.35 \%$ of the respondents gave a negative response to Performance Declaration and Professional Allowance Disbursement in the determination of the annuitant. Thus it can be said that the Declaration Performance and Professional Allowance Disbursement in the determination of beneficiaries is not fully in accordance with predetermined rules.

Moreover, determination of professional allowances is not yet fully in accordance with the applicable rules. 
Professional allowances are not fully paid every three month, and are not on time. In other words, the professional allowance does not fully comply with the rules that have been defined.

There are $0.73 \%$ of the respondents gave a negative response to professional allowance usefulness that is far below the $10 \%$ tolerance limit. This means the Professional Allowance have a positive value for teachers.

There are $1.75 \%$ of the respondents gave a negative response to performance Provision of Professional Allowance Declaration in terms of control benefits which were far below the tolerance limit of $10 \%$, and there are not any attributes that negatively elicit responses above the threshold of tolerance of $10 \%$. Thus, the Declaration Performance Professional Allowance in the controlling allowance has been running in accordance with the conditions. 24 hours compulsory teaching subjects felt hard to fulfill because there are schools with the number of class hours less than 24 hours of lessons. There are teachers willing to teach mulok and IT because it is not counted as a teaching load.

\section{B. The Effect of Teacher Professional Allowance on Teacher Performance as an Educator}

The result of simple regression analysis of professional allowance decrease (X) on Teacher Performance as an educator (Y1) obtained value $F=4.319$ with significance $\alpha=0.039$, smaller than acceptance limit $\alpha=0.05$. This can be concluded that there is a significant linear effect of professional allowance on the Teacher Performance as an Educator.

Results of calculation to find regression direction of coefficient $b=0.074$ from constant $a=2.92$ thus form regression of variable can be formulated with equation $\hat{\mathrm{Y}}=$ $2.92+0.074 \mathrm{X}$. The direction of the regression equation can be described as follows. The result of SPSS calculation shows the correlation coefficient between professional teacher allowance (X) with teacher performance as an educator (Y1) $\mathrm{r}=0.148$ with coefficient determination 0.022 , and it can be concluded that there is a positive relationship between teacher professional allowance with teacher performance as an educator.

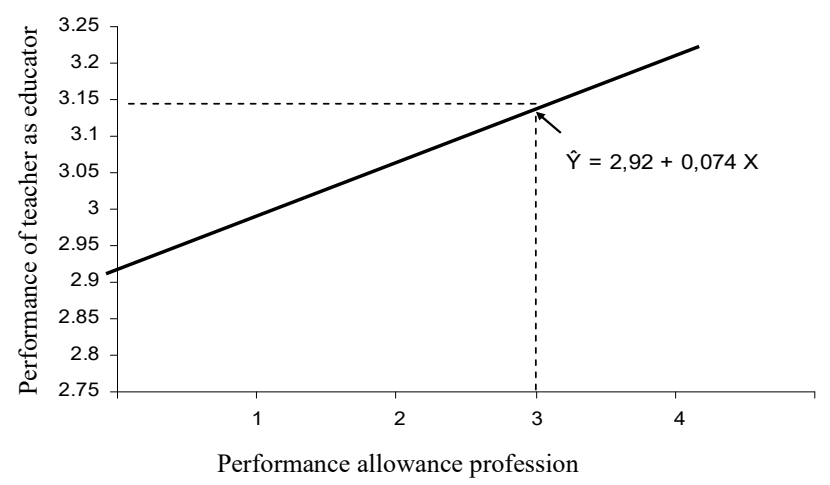

Fig. 1. Diagram of regression line $\hat{Y}=2.92+0.074 X$

\section{The Influence of Professional Allowance on Teacher Professionalism}

The Result of simple regression analysis of variable of performance of teacher profession allowance $(\mathrm{X})$ to teacher professionalism (Y2) obtained the value of $\mathrm{F}=0.475$ with significance $\alpha=0.491$. This means that the regression between teacher professional allowance $(\mathrm{X})$ to teacher professionalism (Y2) is not significant at $\alpha=0.05$. This means that the direction of regression is not linear. Thus the professionalism of teachers cannot be predicted by the influence of teachers' professional allowance. That is, teacher professional allowance does not affect linearly to the professionalism of teachers.

The result of the calculation shows the correlation coefficient between teacher professional allowance (X) and teacher professionalism (Y2), with a correlation coefficient between teacher professional allowance with teacher professionalism $r=0.05$ with a coefficient of determination $r^{2}$ $=0.002$. It can be concluded that the relationship between professional allowance and teacher professionalism is very small (less than 1\%) and insignificant

\section{CONCLUSION}

The performance of teachers as educators in the category is generally very well. This is reflected in each component that supports the performance of teachers as educators, namely the competence of teachers in preparing to teach, competence in implementing the teaching and learning, and competence in conducting learning evaluation all in the good and very good category. However, the competence of teachers in evaluating learning was in the category 'enough'. Therefore, the policymakers need to pay attention to the improvement of teacher competence in conducting learning evaluation.

The performance of teachers as professionals is very low, mostly in fewer categories. This is reflected in the ability of professional and self-development as educators that are still very low.

The correlation between professional teacher allowance $(\mathrm{X})$ and teacher performance as educator (Y1) is positive, while the correlation between teacher professional allowances $(\mathrm{X})$ with teacher professionalism (Y2) is very small (less than $1 \%$ ), so the relationship can be considered meaningless.

\section{REFERENCES}

[1] Darling, L.\& Hammond. 2000. Teacher Quality and Student Achievement: A Review of State Policy Evidence. EPAA Journals in Education. Vol 8, July, 1, 2000, 1.

[2] Whitty, G. (2000). Teacher professionalism in new times. Journal of InService Education, 26(2), 281-295

[3] Hu, G. 2004. English Language Education in China: Policies, Progress, and Problems. Language Policy. March 2005, Volume 4, Issue 1, pp 524.

[4] Foster, P. \& Wilding, P. 2000.Whither Welfare Professionalism?. Social Policy and Administration Vol 34 , No. 2, June 2000, pp.143-59.

[5] Wang, L.et al. 2014. Teacher professionalism under the recent reform of performance pay in Mainland China. PROSPECTS Comparative Journal of Curriculum, Learning, and Assessment. Volume 44, Issue 3, pp 429-443

[6] Bringle, R.G. \& Hatcher, J. A. 1996. Implementing Service Learning in Higher Education. Journal Of Higher Education, Vol. 67, No. 2. 
[7] Moore, D. E., green, J. S., \& Gallis, H. A. 2009. Achieving desired results and improved outcomes: Integrating planning and assessment throughout learning activities. Journal of Continuing Education in The Health Professions-29(1).

[8] Garet, M. S. et al. 2001. What Makes Professional DevelopmentEffective? Results From a National Sampleof Teachers. American Educational Research Journal Winter 2001, Vol. 38, No. 4, pp. $915-945$.
[9] Berry, A., \& Loughran, J. J.2002. Developing an understandingof learning to teach in teacher education. In J. Loughran, \& T.Russell (Eds.),Improving teacher education practices throughself-study(pp. 1329). London: RoutledgeFalmer.

[10] Hoyle, E. 1974. Professionality, professionalism and control in teaching. London Educational Review, 3(2), 13-19 